\title{
Stratigraphic Cross Sections of the Niobrara Interval of the Upper Cretaceous Cody Shale in the Bighorn Basin, Wyoming and Montana
}

Pamphlet to accompany

Scientific Investigations Map 3422 



\section{Stratigraphic Cross Sections of the Niobrara Interval of the Upper Cretaceous Cody Shale in the Bighorn Basin, Wyoming and Montana}

By Thomas M. Finn

Pamphlet to accompany

Scientific Investigations Map 3422 


\title{
U.S. Department of the Interior \\ DAVID BERNHARDT, Acting Secretary
}

\author{
U.S. Geological Survey \\ James F. Reilly II, Director
}

U.S. Geological Survey, Reston, Virginia: 2019

For more information on the USGS - the Federal source for science about the Earth, its natural and living resources, natural hazards, and the environment-visit https://www.usgs.gov or call 1-888-ASK-USGS.

For an overview of USGS information products, including maps, imagery, and publications,

visit https://store.usgs.gov.

Any use of trade, firm, or product names is for descriptive purposes only and does not imply endorsement by the U.S. Government.

Although this information product, for the most part, is in the public domain, it also may contain copyrighted materials as noted in the text. Permission to reproduce copyrighted items must be secured from the copyright owner.

Suggested citation:

Finn, T.M., 2019, Stratigraphic cross sections of the Niobrara Interval of the Upper Cretaceous Cody Shale in the Bighorn Basin, Wyoming and Montana: U.S. Geological Survey Scientific Investigations Map 3422, pamphlet 19 p., 1 sheet [cross section], https://doi.org/10.3133/sim3422.

ISSN 2329-132X (online) 


\section{Contents}

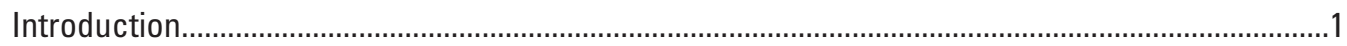

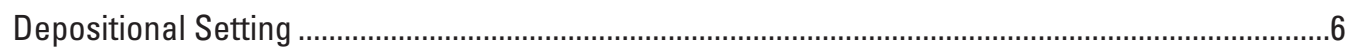

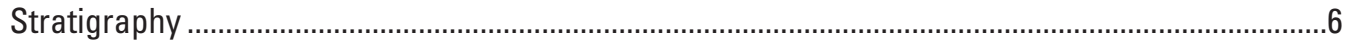

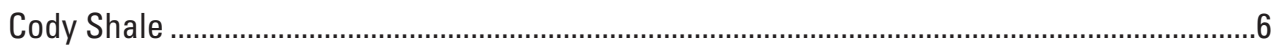

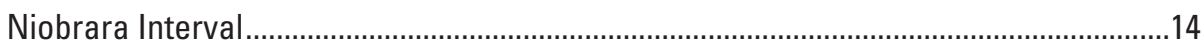

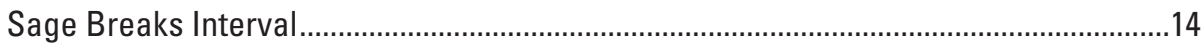

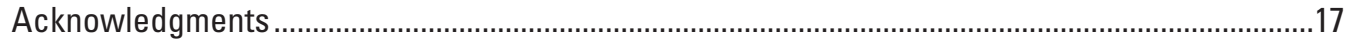

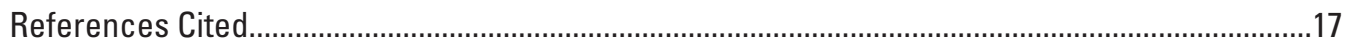

\section{Figures}

1. Generalized map of the Rocky Mountain region showing the locations of

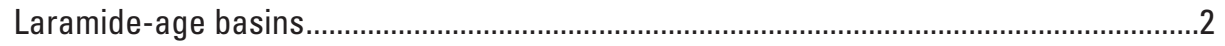

2. Index map of the Bighorn Basin showing major structural elements and principal

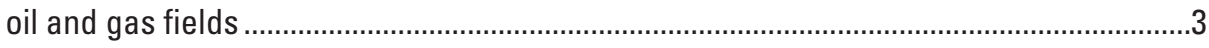

3. Index map of the Bighorn Basin showing the cross section lines presented on the

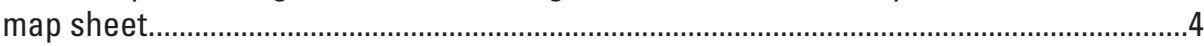

4. Type log of Lower and lowermost Upper Cretaceous rocks in the southeastern part

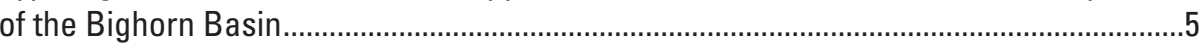

5. Map showing approximate extent of the Western Interior Seaway in North America during late Coniacian (Scaphites depressus Zone) ...........................................7

6. Regional northwest-southeast stratigraphic cross section of Cretaceous rocks in

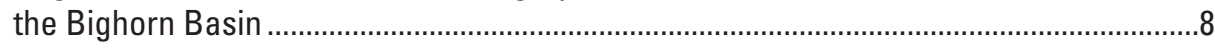

7. Schematic reconstruction of the Rocky Mountain region showing Niobrara depositional trends during late Coniacian (Scaphites depressus Zone) time...................9

8. Correlation chart showing stratigraphic relations of mid-Cretaceous rocks in the Bighorn Basin and correlation with equivalent rocks at various localities in the Wind River, Powder River, northwestern Black Hills, and Denver Basins........................10

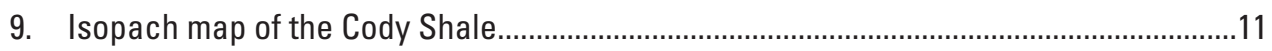

10. Isopach map of the lower shaly member of the Cody Shale.........................................12

11. Isopach map of the upper part of the Cody Shale ....................................................13

12. Isopach map of the Niobrara interval in the lower part of the Cody Shale .....................15

13. Isopach map of the Sage Breaks equivalent interval in the lower part of the Cody

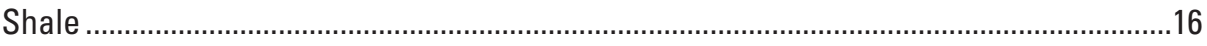




\section{Conversion Factors}

U.S. customary units to International System of Units

\begin{tabular}{lcl}
\hline & Multiply & \multicolumn{1}{c}{ Bo obtain } \\
\hline inch (in.) & Length & \\
foot (ft) & 25.4 & millimeter $(\mathrm{mm})$ \\
mile (mi) & 0.3048 & meter (m) \\
\hline & 1.609 & kilometer $(\mathrm{km})$ \\
\hline square mile $\left(\mathrm{mi}^{2}\right)$ & Area & \\
\hline
\end{tabular}

\section{Datum}

Horizontal coordinate information is referenced to the North American Datum of 1983 (NAD 83). Altitude, as used in this report, refers to distance above sea level. 


\title{
Stratigraphic Cross Sections of the Niobrara Interval of the Upper Cretaceous Cody Shale in the Bighorn Basin, Wyoming and Montana
}

\author{
By Thomas M. Finn
}

\section{Introduction}

The Bighorn Basin is a large intermontane structural and sedimentary basin that formed in the Rocky Mountain foreland during the Laramide orogeny. It is about 180 miles (mi) long, $100 \mathrm{mi}$ wide, and encompasses about 10,400 square miles $\left(\mathrm{mi}^{2}\right)$ in north-central Wyoming and a small part of south-central Montana (fig. 1). The basin is bounded on the northeast by the Pryor uplift, on the east by the Bighorn uplift, and on the south by the Owl Creek uplift. The western and northwestern margins are formed by the Absaroka volcanics and Beartooth uplift, respectively. The northern boundary is formed by the Nye-Bowler lineament (figs. 1 and 2).

According to Hewett and Lupton (1917), oil was first discovered in the Bighorn Basin in 1884 at an oil seep near what is now the Bonanza oil field along the east margin of the basin (fig. 2). Several shallow wells were subsequently drilled in the area, but no hydrocarbons were found in commercial amounts (Hewitt and Lupton, 1917). It wasn't until 1906 that the first commercial hydrocarbon production in the Bighorn Basin was established from Cretaceous reservoirs at Garland field (fig. 2) (Biggs and Espach, 1960; Fox and Dolton, 1996). Since then, many important conventional oil and gas fields have been discovered that produce from reservoirs ranging in age from Cambrian through Tertiary; these fields primarily produce from anticlinal traps around the margins of the basin (Fox and Dolton, 1989, 1996; De Bruin, 1993) (fig. 2). In addition, a potential unconventional (continuous) basin-centered gas accumulation may be present in low-permeability Cretaceous sandstones in the deeper parts of the basin (Ryder, 1987; Surdam and others, 1997; Johnson and Finn, 1998; Johnson and others, 1999; Finn and others, 2010). It has been suggested that various Upper Cretaceous marine shales, including the Cody Shale, are potential source rocks for many of these accumulations (see for example, Hagen and Surdam, 1984; Meissner and others, 1984; Ryder, 1987; Fox and Dolton, 1989, 1996; Johnson and Keighin, 1998; Nuccio and Finn, 1998; Finn, 2014). With recent advances and success in horizontal drilling and multistage fracture stimulation, there has been an increase in exploration and completion of wells in equivalent Upper
Cretaceous marine shale source rocks in other Rocky Mountain Laramide basins (Matthews, 2011; Sonnenberg, 2011; Williams and Lyle, 2011; Durham, 2012a,b, 2013; Taylor and Sonnenberg, 2014; Hawkins, 2016).

The stratigraphic cross sections presented in this report were constructed as part of a U.S. Geological Survey (USGS) project to characterize and evaluate the undiscovered continuous (unconventional) oil and gas resources of the Niobrara interval of the Upper Cretaceous Cody Shale in the Bighorn Basin in north-central Wyoming and south-central Montana. The cross sections show the stratigraphic relationship and distribution of the Niobrara interval and associated rocks in the lower part of the Cody Shale.

Three cross sections were constructed using borehole geophysical logs from 45 wells drilled for oil and gas exploration and production (fig. 3, and map sheet). The cross sections include the stratigraphic interval extending from the uppermost part of the Frontier Formation to the middle part of the Cody Shale (map sheet). The datum is the base of the "chalk kick" marker bed, a distinctive resistivity peak or zone, in the lower part of the Cody Shale. This datum was selected because it is easily identified on most well logs and is present throughout the basin (fig. 4, and map sheet).

Gamma ray and (or) spontaneous potential (SP) logs were used in combination with resistivity logs to identify and correlate units. Gamma ray and SP logs are typically used to differentiate between sandstone and shale; however, in the Bighorn Basin, the SP response is subdued in some sandstone intervals showing little curve deflection. In areas with high drilling density, logs from wells located between control wells on the cross sections were used to aid in making correlations. Marine molluscan index fossils collected from nearby outcrop sections were projected into the subsurface to help determine the relative ages of the strata and also aid in correlation. The sources for the fossil data are from Cobban (1951), Cobban (1969), Gill and Burkholder (1979), Merewether and others (2010), and McKinney and Cobban (2018). For all cross sections on the map sheet, the horizontal scale is about 1 inch (in.) $=5.75 \mathrm{mi}$ and the vertical scale is about 1 in. $=500 \mathrm{ft}$. 


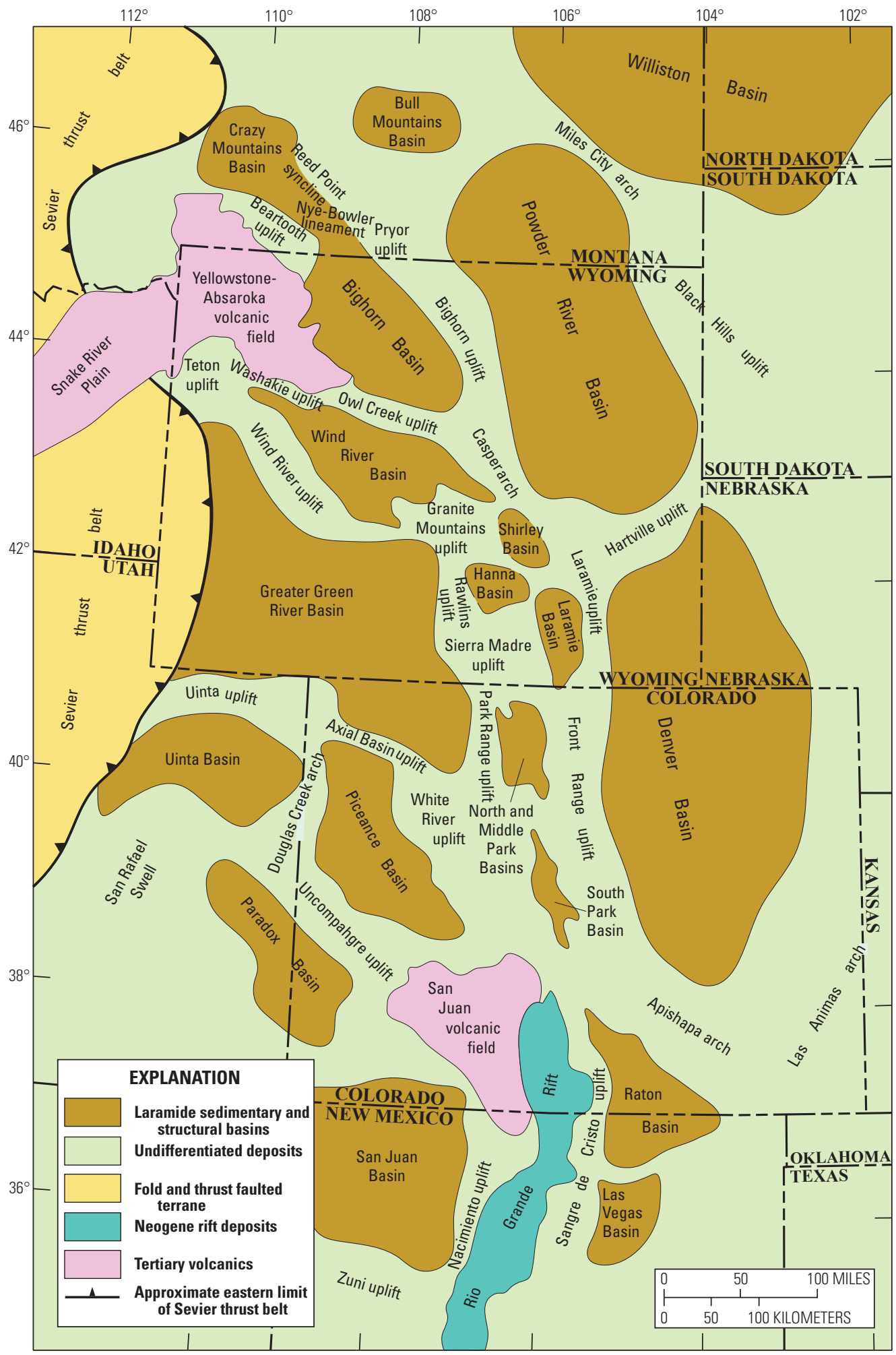

Base from U.S. Geological Survey, 1985, 1:5,000,000

Albers Equal Area Conic projection

Figure 1. Generalized map of the Rocky Mountain region showing the locations of Laramide-age basins. 


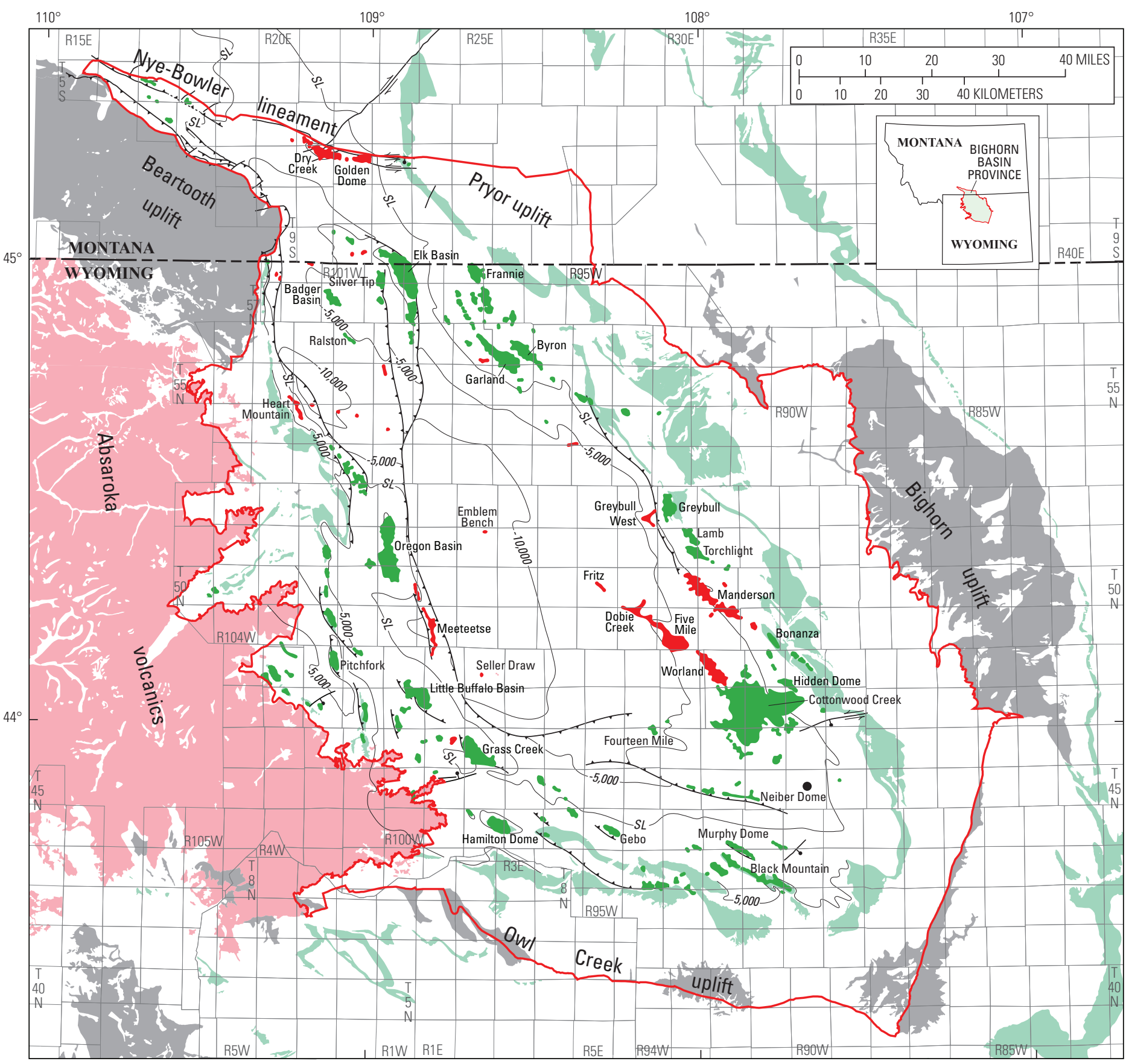

\section{EXPLANATION \\ Tertiary volcanic rocks \\ Frontier Formation outcrop \\ Precambrian rocks \\ Bighorn Basin Province boundary Thrust fault-Sawteeth on upper plate. Dashed where location \\ alt-Bar an fauld \\ downthrown side High-angle fault \\ $\leftrightharpoons$ Wrench fault-Arrows show relative motion \\ $-5,000-$ Structure contour-Drawn at the base of the "chalk kick" marker bed. Contour interval, 5,000 feet. \\ Byron Oil field and name \\ Fritz Gas field and name \\ - Pike Resources Federal 1-15} type log

Base from U.S. Geological Survey, 2010,

$1: 2,000,000$-scale digital data

Lambert Conformal Conic projection

Standard parallels $41^{\circ}$ and $45^{\circ}$

Central meridian- $107^{\circ} 30^{\prime}$

Latitude of origin $41^{\circ}$, meters

North American Datum of 1983 (NAD 83)
Figure 2. Index map of the Bighorn Basin showing major

structural elements and principal oil and gas fields. Structure contours are drawn at the base of the "chalk kick" marker bed. Contour interval is 5,000 feet. $S L$, sea level. 


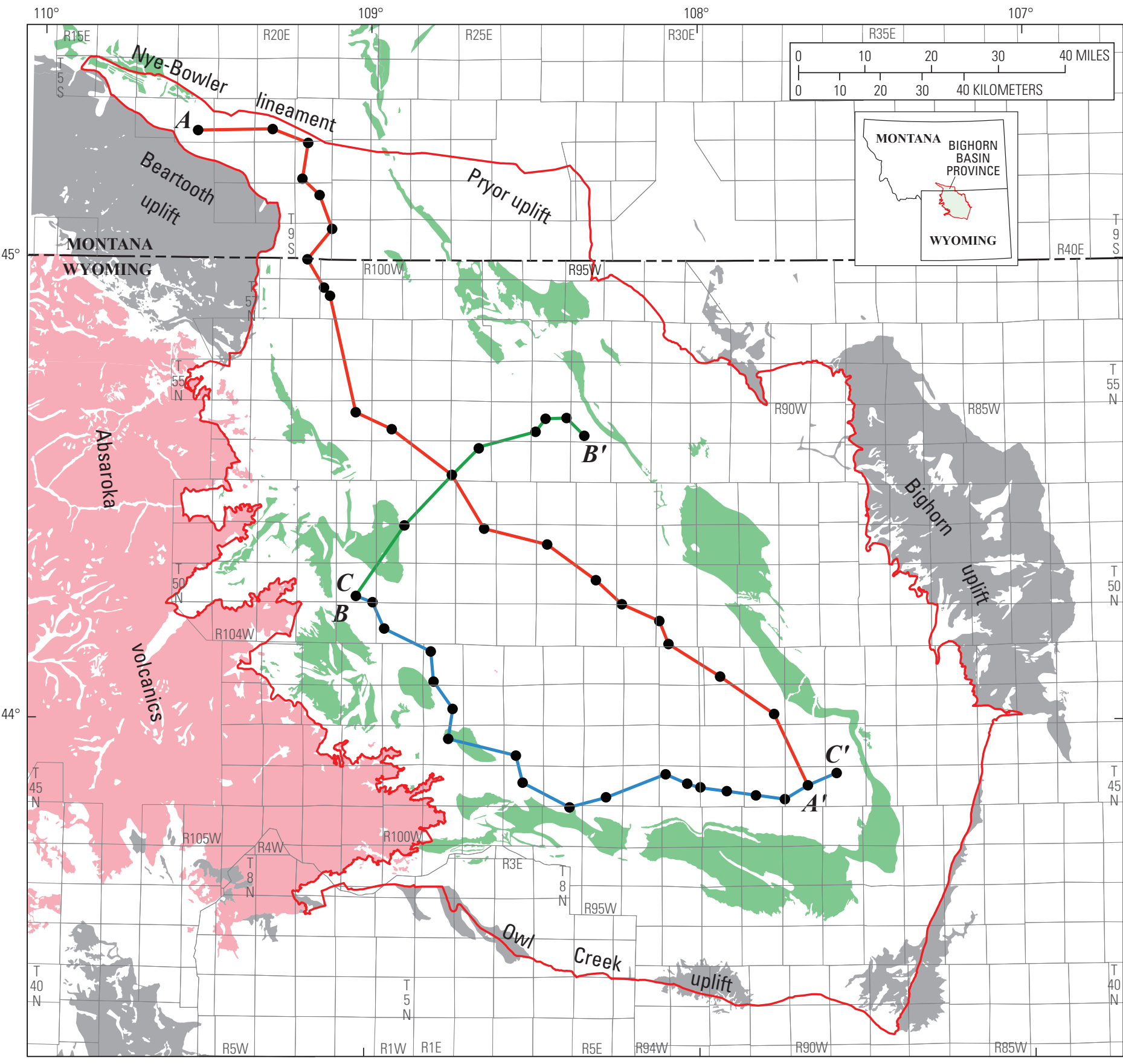

\section{EXPLANATION}

Tertiary volcanic rocks

Cody Shale outcrop

Precambrian rocks

Bighorn Basin Province boundary

$A-A^{\prime}$ Line of section

- Well location

Base from U.S. Geological Survey, 2010 ,

$1: 2,000,000$-scale digital data

Lambert Conformal Conic projection

Standard parallels $41^{\circ}$ and $45^{\circ}$

Central meridian- $107^{\circ} 30^{\circ}$

North American Datum of 1983 (NAD 83)

Figure 3. Index map of the

Bighorn Basin showing the cross section lines presented on the map sheet. 
API 4904320512

Pike Resources Federal 1-15 sec. 15 , T. 45 N., R. 90 W.

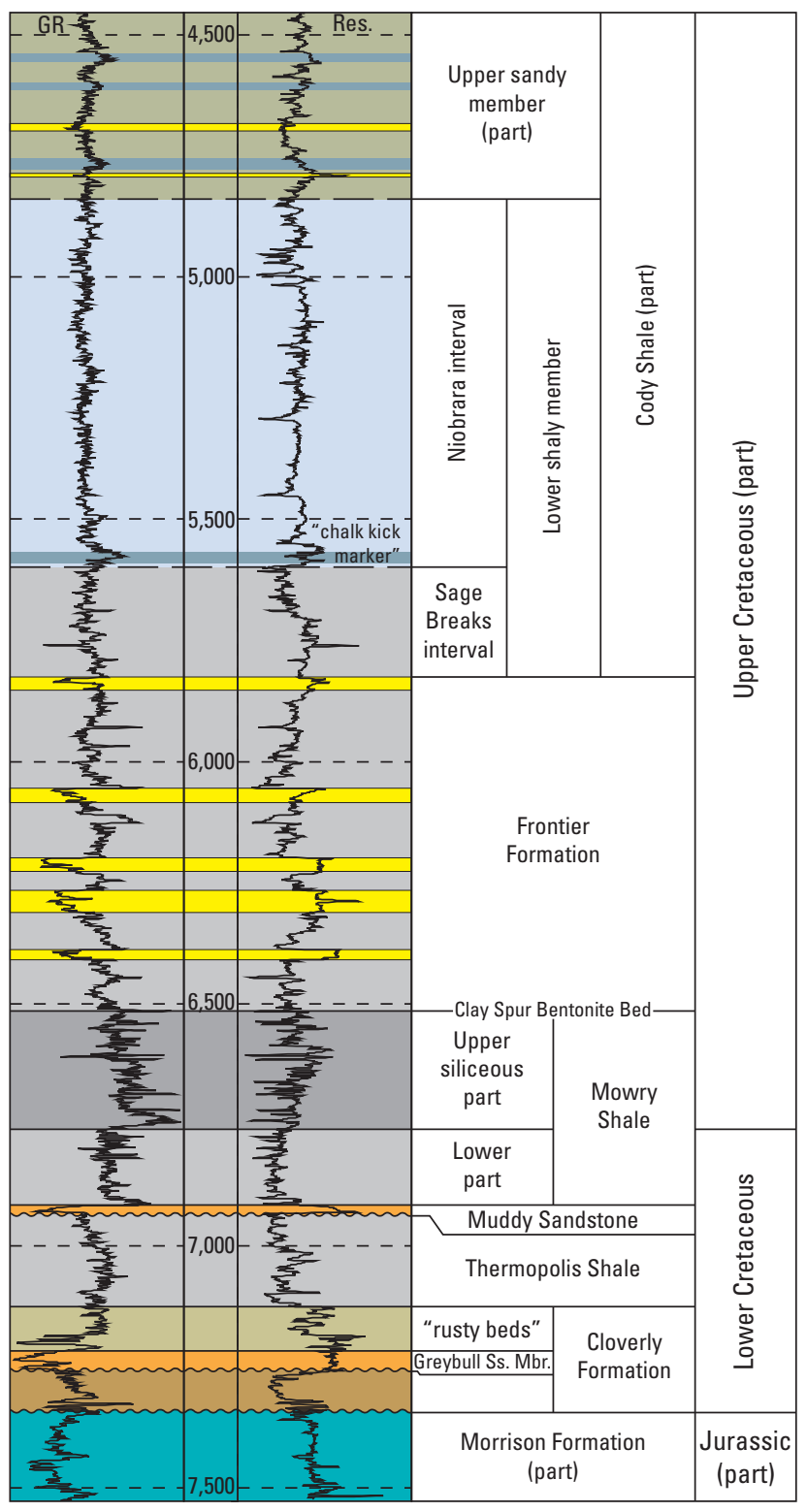

\section{EXPLANATION}

Floodplain and lacustrine sandstone, shale, and conglomerate

Tidal sandstone, siltstone, and shale

Estuarine and fluvial sandstone

Marine sandstone, shale, sandy shale, and siltstone

Marine and marginal marine sandstone and siltstone

Marine shale, calcareous shale, sandy shale, silty shale, and marl

Marine shale

Siliceous marine shale

Laterally persistant zone within the Cody Shale showing higher gamma ray intensity Undifferentiated deposits

Figure 4. Type log of Lower and lowermost Upper Cretaceous rocks in the southeastern part of the Bighorn Basin. GR, gamma ray log; Res., resistivity log; Ss, sandstone; Mbr., member. Location shown in figure 2. 
Stratigraphic Cross Sections, Niobrara Interval, Upper Cretaceous Cody Shale Bighorn Basin, Wyom. and Mont.

\section{Depositional Setting}

During Late Jurassic and Cretaceous time, that part of Wyoming and Montana that is now the Bighorn Basin was located in the western part of the Western Interior Basin, an elongate north-south foreland basin, that developed to the east of the tectonically active Cordilleran highlands of western North America (fig. 5). From Albian to Maastrichtian time (latest Early Cretaceous to latest Cretaceous time), the foreland basin was periodically flooded by a broad epicontinental sea, referred to as the Western Interior Seaway (WIS), which developed in response to foreland basin subsidence and eustatic sea-level fluctuations (Steidtmann, 1993). At its maximum extent, the WIS extended for more than 3,000 mi from the Arctic Ocean to the Gulf of Mexico (fig. 5) (Kauffman, 1977). Erosion of the Cordilleran highlands supplied sediment to the western part of the basin by eastward-flowing streams; whereas, the eastern part of the basin was adjacent to the topographically low and stable North American craton and received little sediment (Molenaar and Rice, 1988). The shoreline repeatedly advanced and retreated across the western part of the basin resulting in a complex pattern of intertonguing marine and nonmarine deposits (fig. 6). Marginal marine and nonmarine deposits are represented by eastward-thinning wedges of marginal marine and nonmarine sandstone, siltstone, shale, carbonaceous shale, and coal. The marine deposits are represented by westward-thinning tongues of marine shale, siltstone, and marine sandstone (fig. 6). The marine sediments were deposited during widespread transgressions creating highstand conditions as the seaway deepened, limiting clastic input, and at times forming anoxic bottom conditions favorable for the preservation of organic matter (Gries and others, 1992). In addition, these transgressions produced two widespread episodes of carbonate deposition in the WIS; the first resulted in the deposition of the Upper Cretaceous Greenhorn Formation, the second resulted in the deposition of the Upper Cretaceous Niobrara Formation and its equivalents (Longman and others, 1998; Sonnenberg, 2011). The Niobrara is characterized by deposition of chalks and marls composed of foraminifer and coccolith debris that accumulated in the sediment-starved eastern part of the seaway (Longman and others, 1998; Sonnenberg, 2011). The chalks grade westward into more siliciclastic beds that were derived from the eroding highlands to the west, diluting the carbonate content in the sediments (Longman and others, 1998; Sonnenberg, 2011) (fig. 7). In the Bighorn Basin, the Niobrara interval is represented by shales, calcareous shales, marls, siltstones, and sandstones in the lower shaly member of the Cody Shale (fig. 6).

\section{Stratigraphy}

A correlation diagram showing the stratigraphic nomenclature for the Cody Shale and associated rocks in the Bighorn Basin and correlative units at various localities in the Wind River, Powder River, and Denver Basins is shown on figure 8.
The Wind River Basin nomenclature is modified from Keefer (1972) and Finn (2017), the western Powder River Basin nomenclature is modified from Merewether (1996), and the northwestern Black Hills and Pueblo, Colo. (Denver Basin) nomenclature is modified from Merewether and others (2011). The stratigraphic relationships and nomenclature for the Bighorn Basin are also illustrated on the regional stratigraphic cross section in figure 6 .

\section{Cody Shale}

The Upper Cretaceous Cody Shale is composed of shales, calcareous shales, marls, bentonites, siltstones, and sandstones, with the amount of sandstone and siltstone increasing in the upper part (Keefer, 1972). The main body of the Cody Shale was deposited during a second-order transgressiveregressive cycle referred to as the "Niobrara Cyclothem" by Kauffman (1977), and ranges in age from latest Turonian to early Campanian. The early to middle Campanian age Claggett Member is the uppermost part of the Cody Shale, and was deposited during a subsequent transgressive-regressive cycle that Kauffman (1977) referred to as the "Claggett Cyclothem" (fig. 8). The lower and upper contacts of the Cody Shale are conformable and interfinger extensively with the underlying Frontier and overlying Mesaverde Formations (fig. 6).

The Cody Shale is about 1,750 feet ( $\mathrm{ft}$ ) thick in the northwestern part of the basin increasing to nearly $3,800 \mathrm{ft}$ in the southeastern part (fig. 9). The eastward thickening is due to the eastward stratigraphic rise and intertonguing of the contact between the Cody Shale and the overlying Mesaverde Formation, and in part, to the west to northwest backstepping nature of the Frontier-Cody contact (fig. 6, map sheet). Three members are recognized, in ascending order: (1) the unnamed lower shaly member (Keefer, 1972), (2) the unnamed upper sandy member (Keefer, 1972), and (3) the Claggett Member or Claggett Shale in Montana (Keefer and others, 1998) (figs. 6 and 8).

The lower shaly member, extending from the top of the Frontier Formation to the base of the sandy member, reaches a maximum thickness greater than $1,200 \mathrm{ft}$ in the southern part of the basin and thins northward to about $700 \mathrm{ft}$ (fig. 10). It is composed of gray to black shale, calcareous shale, marl, and bentonite, with minor amounts of siltstone and sandstone that were deposited in an offshore marine environment. The lower shaly member ranges in age from latest Turonian to early Santonian.

The combined thickness of the upper sandy member and the Claggett Member (Claggett Shale) ranges from greater than $2,700 \mathrm{ft}$ in the southeastern part of the basin to around $1,000 \mathrm{ft}$ in the northern part (fig. 11). The upper sandy member consists of buff, or light- to medium-gray sandstones, and gray shales (Johnson and others, 1998). According to Johnson and others (1998), the sandstones are very fine to medium grained, laterally persistent, and exhibit a variety of bedding features including horizontal laminae, ripple laminae, and hummocky cross-bedding. The Claggett Member is composed of light- to medium-gray shale interbedded with thin siltstones and fineto medium-grained sandstones (Johnson and others 1998). 


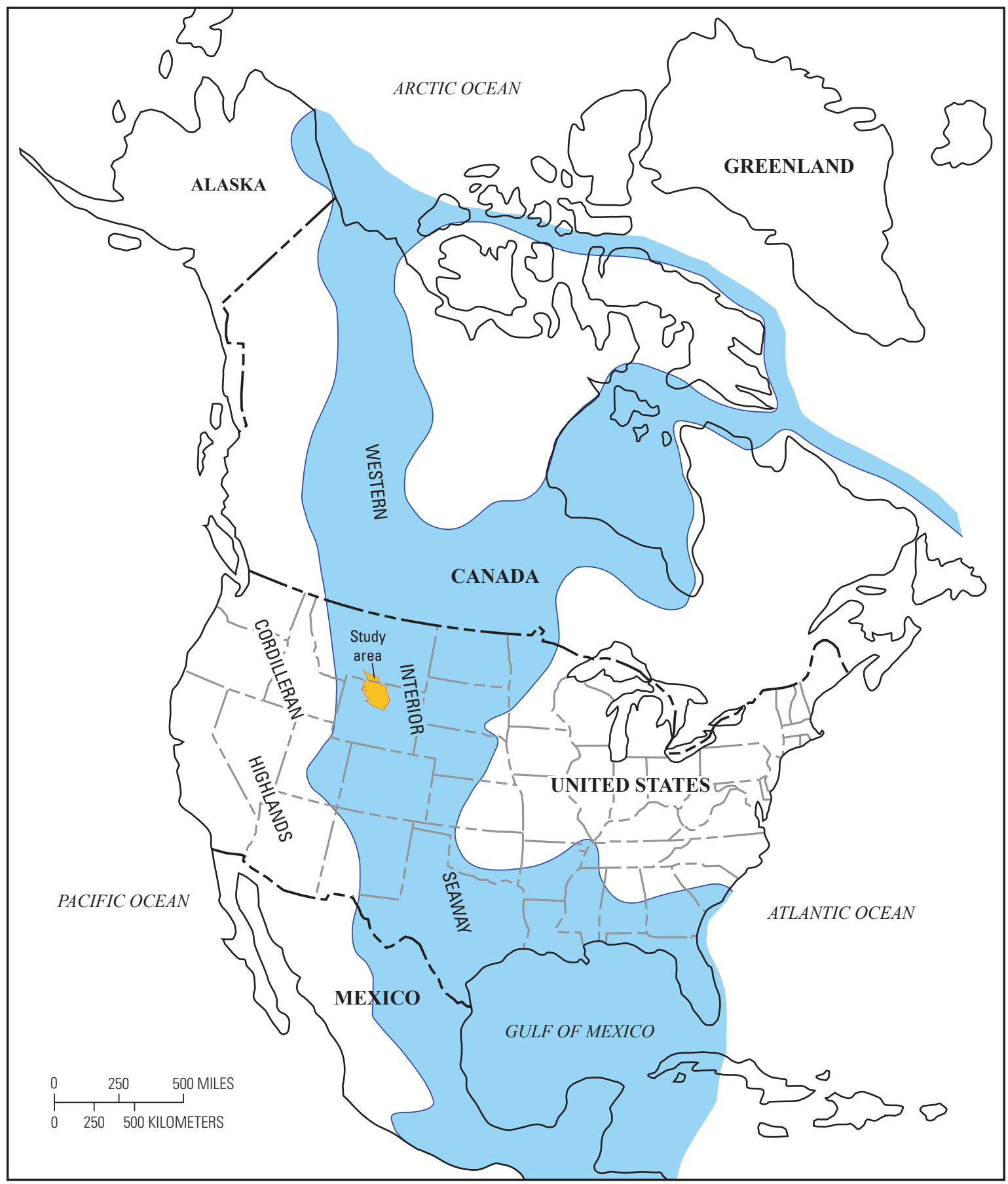

Figure 5. Map showing approximate extent of the Western Interior Seaway in North America during late Coniacian (Scaphites depressus Zone). Modified from Cobban and others (2005). 


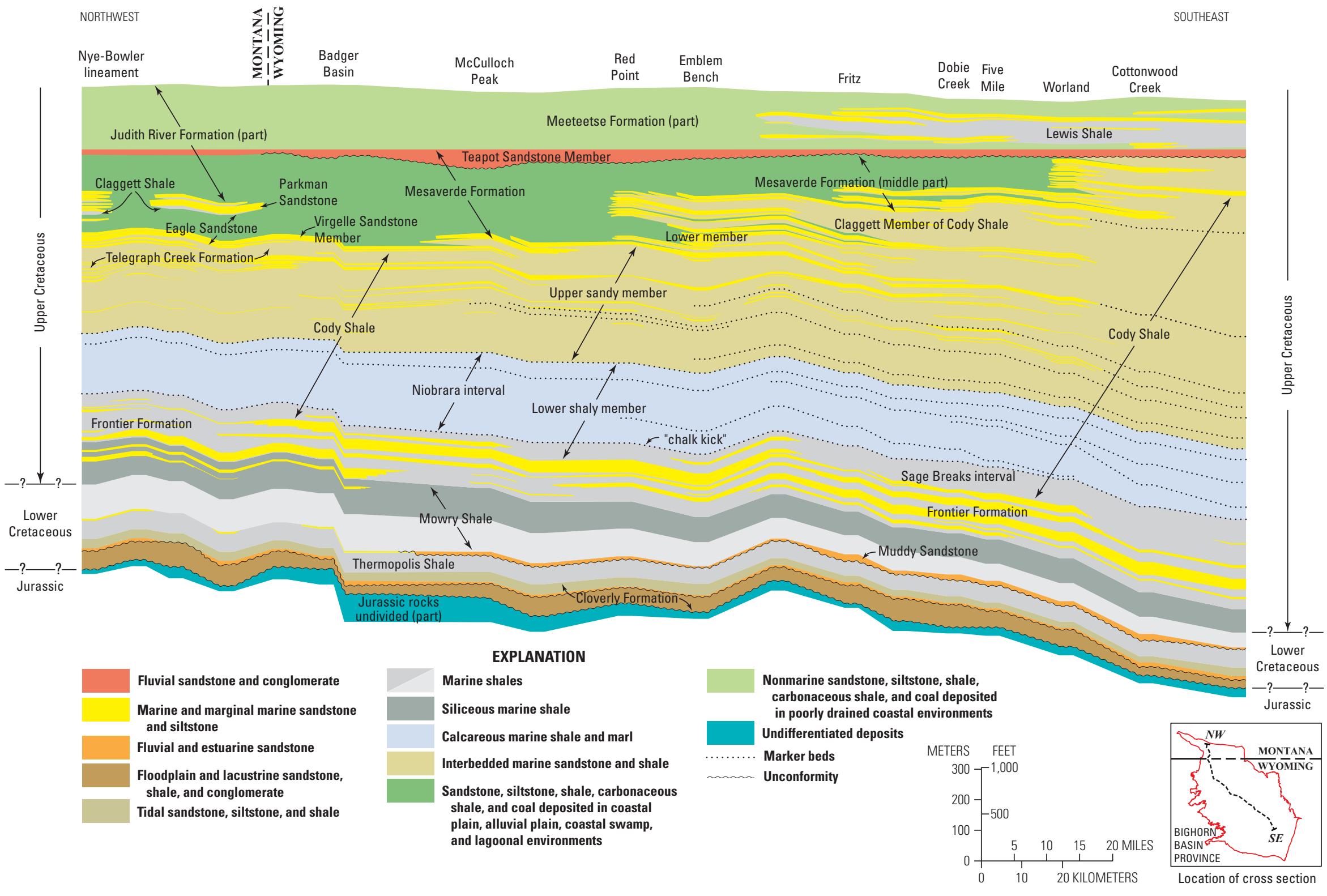

Figure 6. Regional northwest-southeast stratigraphic cross section of Cretaceous rocks in the Bighorn Basin. Modified from Finn (2010). 


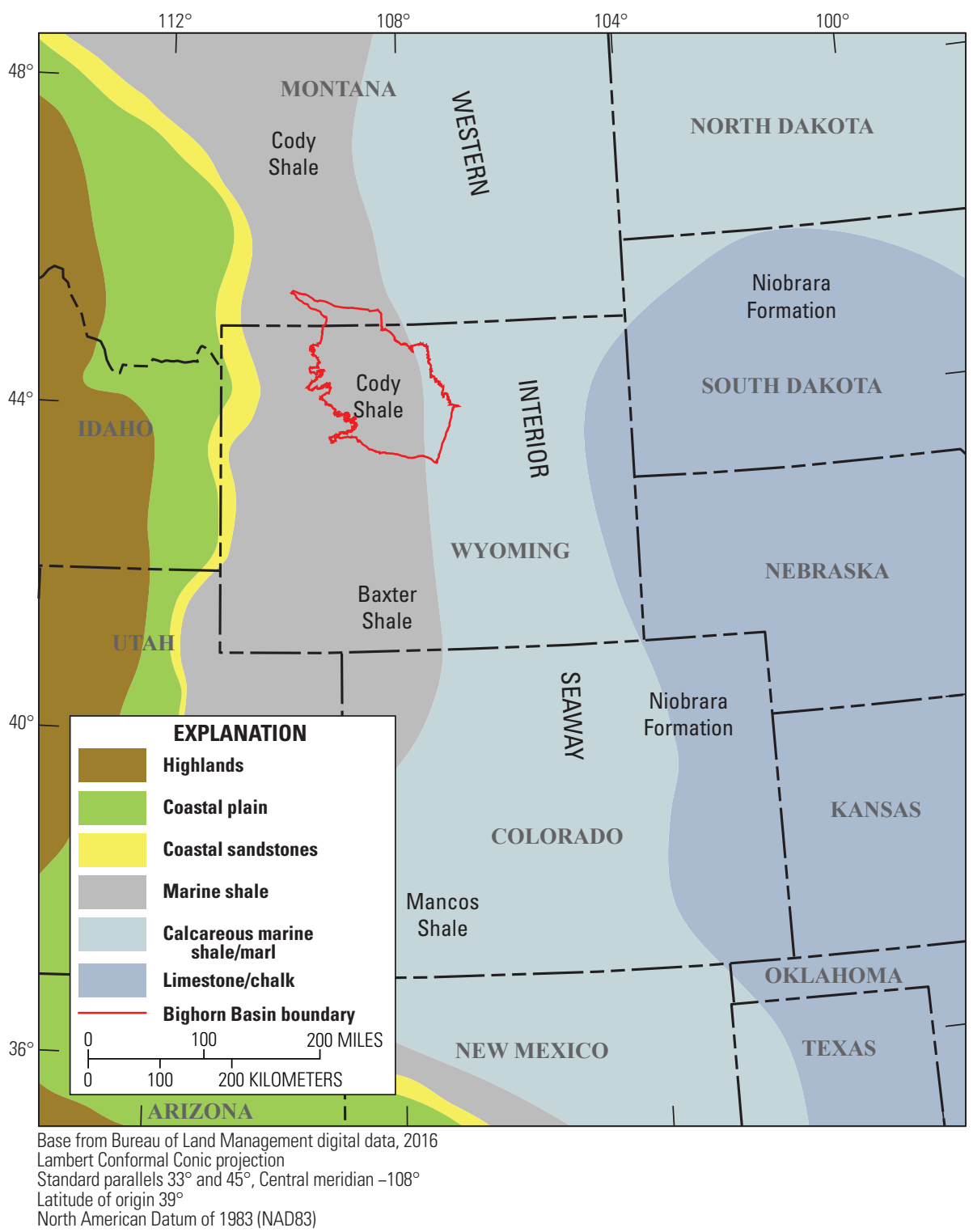

Figure 7. Schematic reconstruction of the Rocky Mountain region showing Niobrara depositional trends during late Coniacian (Scaphites depressus Zone) time. Bighorn Basin outlined in red. Modified from McGookey and others (1972). 


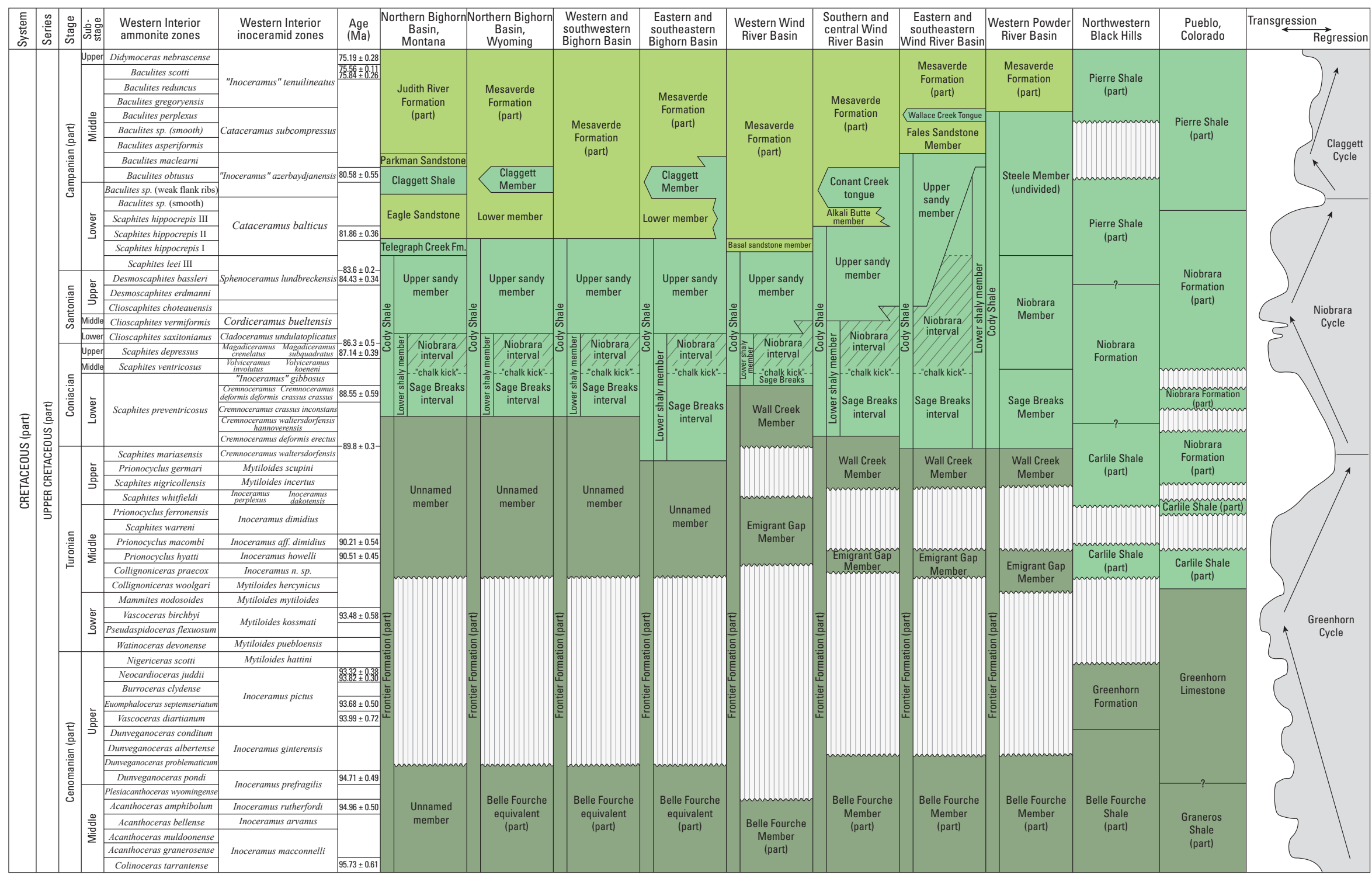

Figure 8. Correlation chart showing stratigraphic relations of mid-Cretaceous rocks in the Bighorn Basin and correlation with equivalent rocks at various localities in the Wind River, Powder River, northwestern Black Hills, and Denver Basins. The diagonal lines represent the Niobrara interval in the Bighorn Basin, as defined in this report. Compiled from Keefer (1972), Hicks and others (1995), Merewether (1996), Kirschbaum and others (2009), Merewether and others (2011), Finn (2014), and Finn (2017). Vertical lines represent periods of erosion or nondeposition. Radiometric ages and fossil zones are from Cobban and others (2006) and Merewether and McKinney (2015). Sea-level curve is modified from Kauffman and Caldwell (1993). 


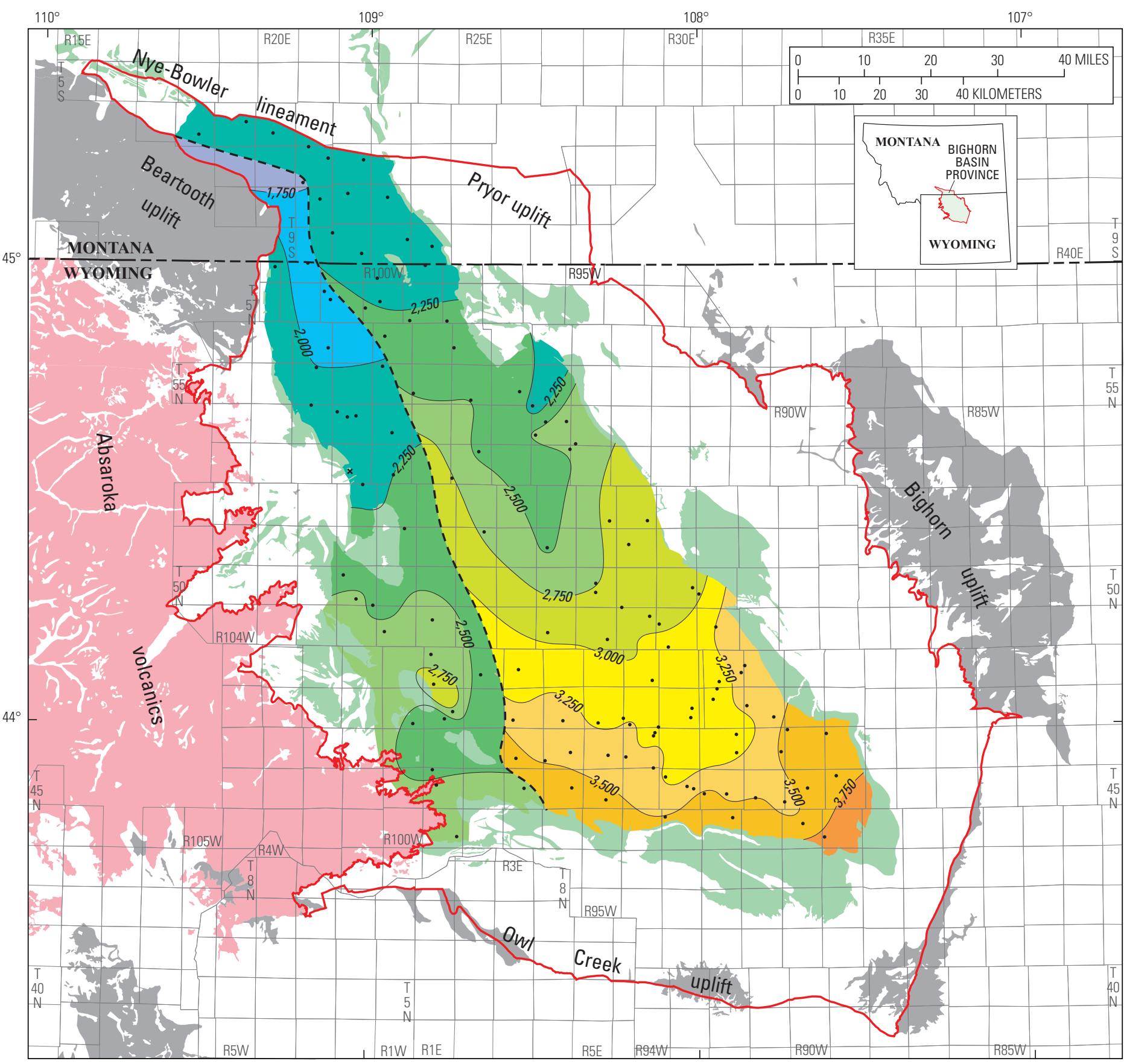

EXPLANATION

Tertiary volcanic rocks

Cody Shale outcrop

Precambrian rocks

Bighorn Basin Province boundary

Western limit of Claggett Member of the Cody Shale

-3,250 - Thickness contour-Contour

interval 250 feet

- Well control point locatio

$\times \quad$ Measured section location

Thickness, in feet

\begin{tabular}{|l|}
\hline$-1,750$ \\
\hline 2,000 \\
$-2,250$ \\
$-2,500$ \\
$-2,750$ \\
$-3,000$ \\
$-3,250$ \\
$-3,500$ \\
$-3,750$ \\
\hline
\end{tabular}

Base from U.S. Geological Survey, 2010

1:2,000,000-scale digital data

Lambert Conformal Conic projection

Standard parallels $41^{\circ}$ and $45^{\circ}$

Central meridian- $107^{\circ} 30^{\circ}$

Latitude of origin $41^{\circ}$, meters

North American Datum of 1983 (NAD 83)

Figure 9. Isopach map of the

Cody Shale. This map includes the interval from the top of the uppermost sandstone in the underlying Frontier Formation to the base of the Mesaverde Formation. This map includes the lower member of the Mesaverde Formation and Claggett Member in Wyoming, and the Eagle Sandstone and Claggett Shale in Montana. Thickness interval 250 feet. 


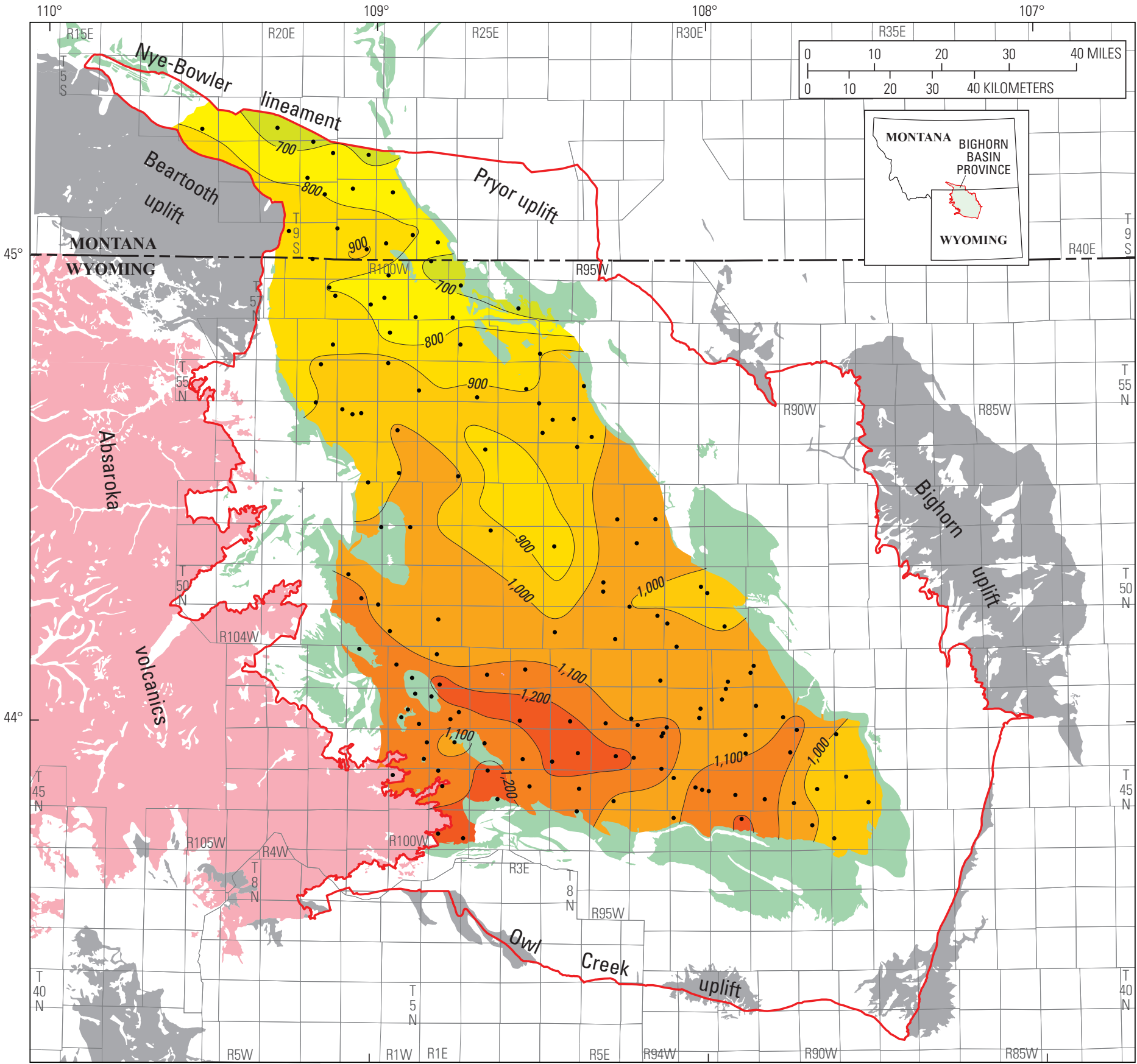

EXPLANATION

Tertiary volcanic rocks

Cody Shale outcrop

Precambrian rocks

Bighorn Basin Province boundary

Thickness contour-Contour

interval 100 feet

Well location

Thickness, in feet

\begin{tabular}{|r|}
\hline-700 \\
-800 \\
\hline \\
\hline \\
$-1,000$ \\
$-1,100$ \\
$-1,200$ \\
\hline
\end{tabular}

Base from U.S. Geological Survey, 2010

1:2,000,000-scale digital data

Lambert Conformal Conic projection

Standard parallels $41^{\circ}$ and $45^{\circ}$

Central meridian-1070 $30^{\prime}$

Latitude of origin $41^{\circ}$, meters

North American Datum of 1983 (NAD 83)

Figure 10. Isopach map of

the lower shaly member of the

Cody Shale. This map includes

the interval from the top of the uppermost sandstone in the

underlying Frontier Formation

to the base of the upper sandy

member of the Cody Shale.

Modified from Finn (2014).

Thickness interval 100 feet. 


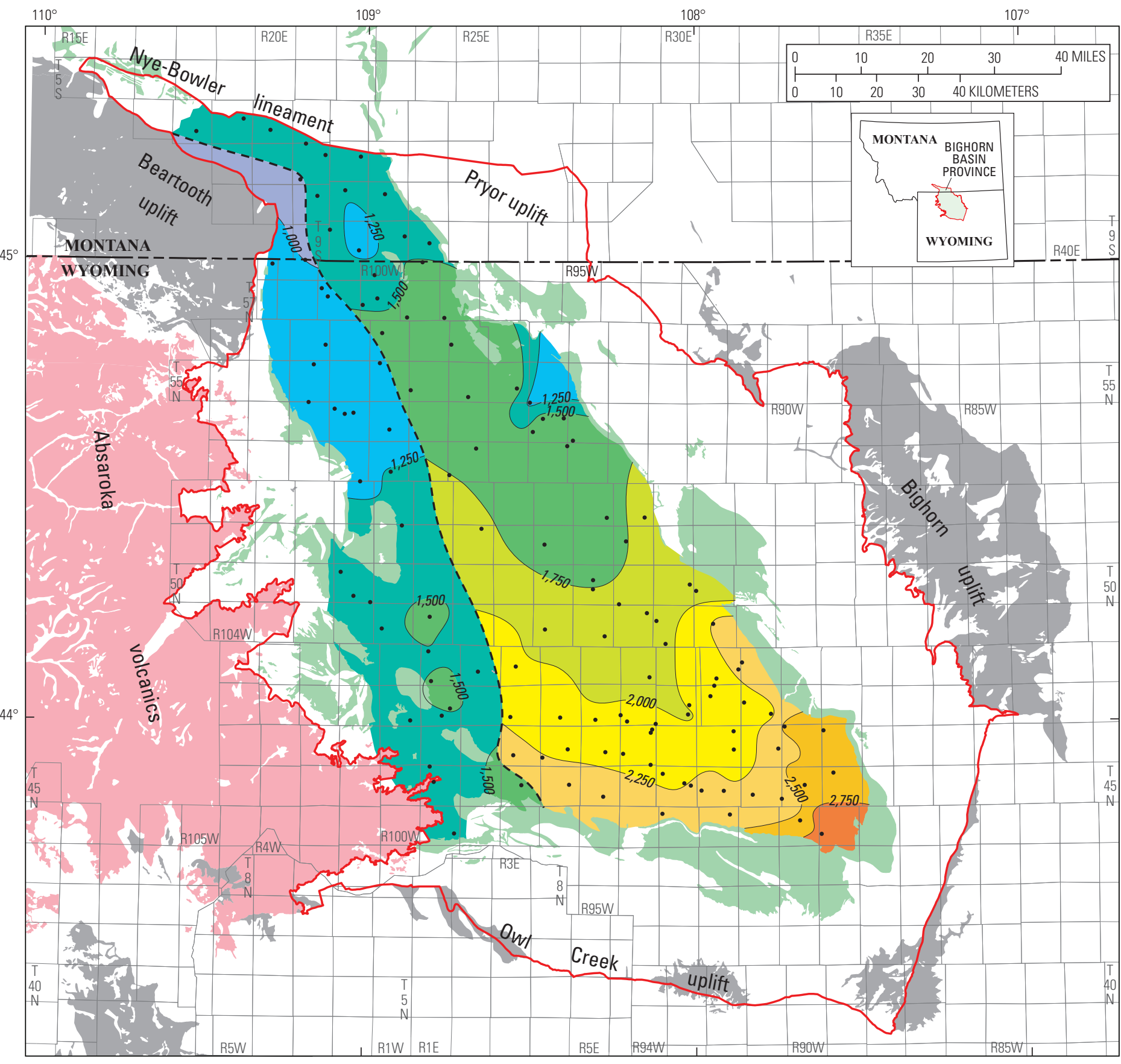

EXPLANATION

Tertiary volcanic rocks

Cody Shale outcrop

Precambrian rocks

Bighorn Basin Province boundary

Western limit of Claggett Member of the Cody Shale

-1,250- Thickness contour-Contour

interval 250 feet

- Well control point location

Thickness, in feet

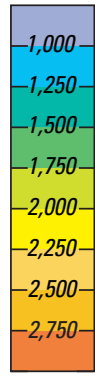

Base from U.S. Geological Survey, 2010

1:2,000,000-scale digital data

Lambert Conformal Conic projection

Standard parallels $41^{\circ}$ and $45^{\circ}$

Central meridian- $107^{\circ} 30^{\prime}$

Latitude of origin $41^{\circ}$ meters

North American Datum of 1983 (NAD 83)

Figure 11. Isopach map of the upper part of the Cody Shale.

This map includes the interval from the base of the upper sandy member to the base of the Mesaverde Formation. This map includes the lower member of the Mesaverde Formation and Claggett Member of the Cody

Shale in Wyoming, and the Eagle Sandstone and Claggett Shale in Montana. Thickness interval 250 feet. 


\section{Niobrara Interval}

The Niobrara interval of the Cody Shale in the Bighorn Basin is represented by gray to black shale, calcareous shale, marl, and bentonite, with minor amounts of siltstone and sandstone. In many samples, the more calcareous zones are often characterized by varying amounts of coccolith-rich fecal pellets that appear as distinctive "white specks" similar to those described by Hattin (1975). A persistent zone or high-resistivity peak identified on resistivity logs in the lower 40-350 ft of the lower shaly member (fig. 4, map sheet), referred to as the "chalk kick" marker by Keefer (1972) and Keefer and others (1998), represents the base of the Niobrara interval and top of the Sage Breaks interval of the Cody Shale in the Bighorn Basin based on correlations projected from the Wind River Basin by Finn (2017). The "chalk kick" marker can be traced in the subsurface throughout most of the basin, and based on sample descriptions from well cuttings, separates noncalcareous shales in the lowermost part of the shaly member from overlying calcareous strata (fig. 4; map sheet). The top of the Niobrara interval is placed at the base of the overlying sandy member. The Niobrara interval thickens from about 500-700 ft in the northern and southeastern parts of the basin to about $1,100 \mathrm{ft}$ in the southwestern part of the basin (fig. 12).
Fossil data reported by Cobban (1951, 1969), Gill and Burkholder (1979), Merewether and others (2010), and McKinney and Cobban (2018) indicate that the Niobrara interval extending from the "chalk kick" marker to the base of the upper sandy member is middle Coniacian to early Santonian in age (fig. 8).

\section{Sage Breaks Interval}

Finn (2014) referred to the interval of the shaly member of the Cody Shale below the "chalk kick" marker and above the top of the Frontier Formation as the Carlile Shale. Here, it is referred to as the Sage Breaks interval to be consistent with the terminology of Finn (2017) for the Wind River Basin, and Merewether (1996), who referred to the interval as the Sage Breaks Member of the Cody Shale in the western part of the Powder River Basin (fig. 8). This interval, ranging in thickness from nearly $350 \mathrm{ft}$ in the eastern and southeastern parts of the basin to less than $50 \mathrm{ft}$ in the central and northern parts, reflects the backstepping stacking pattern of the sandstones in the underlying Frontier Formation (figs. 6, 13; map sheet). Ammonite and inoceramid fossils collected from the underlying Frontier Formation and within the Sage Breaks interval indicate that it is latest Turonian to middle(?) Coniacian in age (fig. 8). 


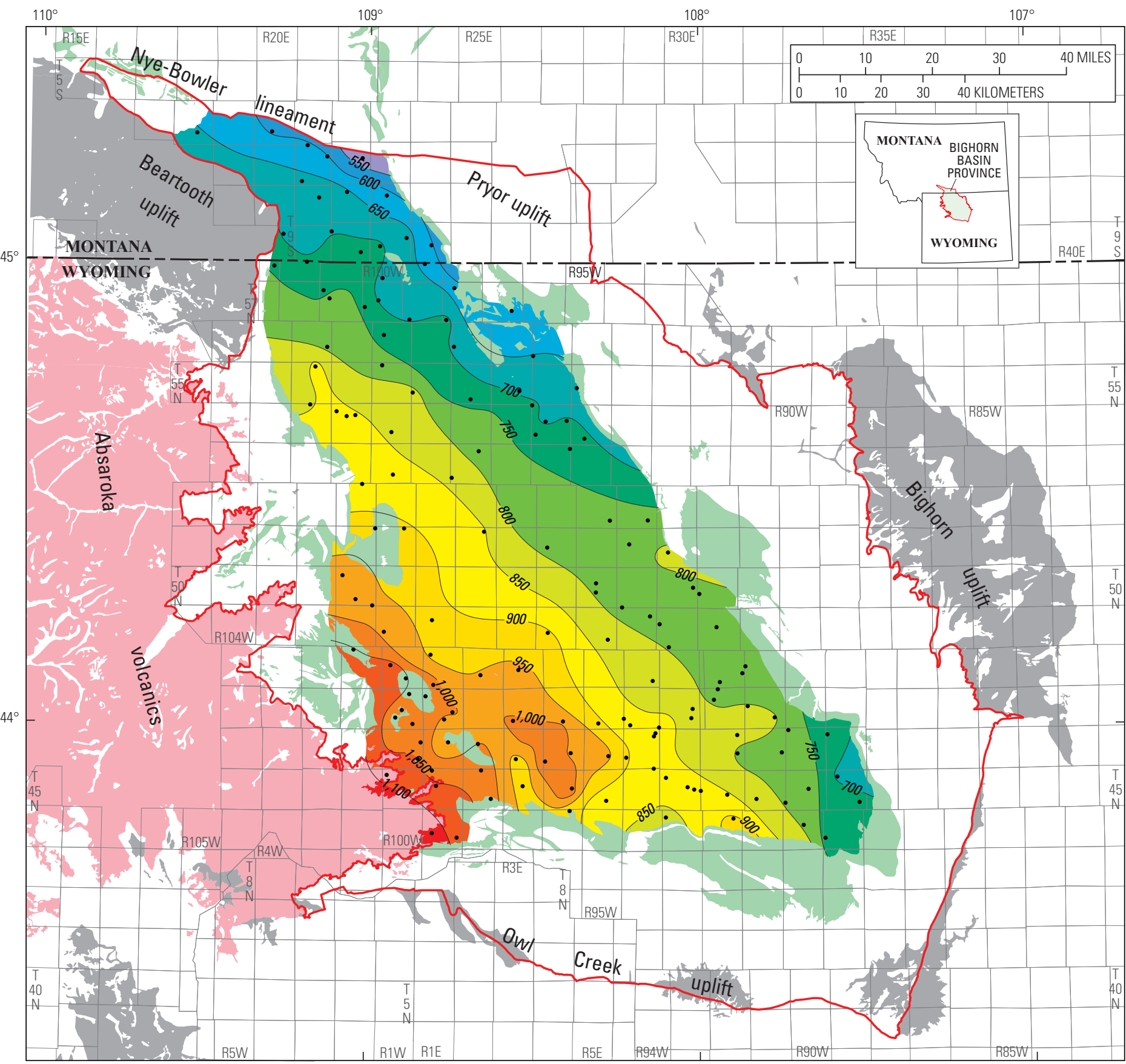

EXPLANATION

Tertiary volcanic rocks

Cody Shale outcrop

Precambrian rocks

Bighorn Basin Province boundary

Thickness contour-Contour

interval 50 feet

- Well location

Thickness, in feet

$$
\begin{array}{|r|}
\hline 550 \\
\hline-600 \\
-650 \\
-700 \\
-750 \\
-800 \\
-850 \\
\hline-900 \\
\hline-950 \\
\hline-1,000 \\
\hline-1,050 \\
\hline-1,100 \\
\hline
\end{array}
$$

Base from U.S. Geological Survey, 2010

1:2,000,000-scale digital data

Lambert Conformal Conic projection

Standard parallels $41^{\circ}$ and $45^{\circ}$

Central meridian- $107^{\circ} 30^{\prime}$

North American Datum of 1983 (NAD 83)

Figure 12. Isopach map of the Niobrara interval in the lower part of the Cody Shale. This map includes the interval from the base of the "chalk kick" marker to the base of the sandy member of the Cody Shale. Modified from Finn (2014). Thickness interval 50 feet. 


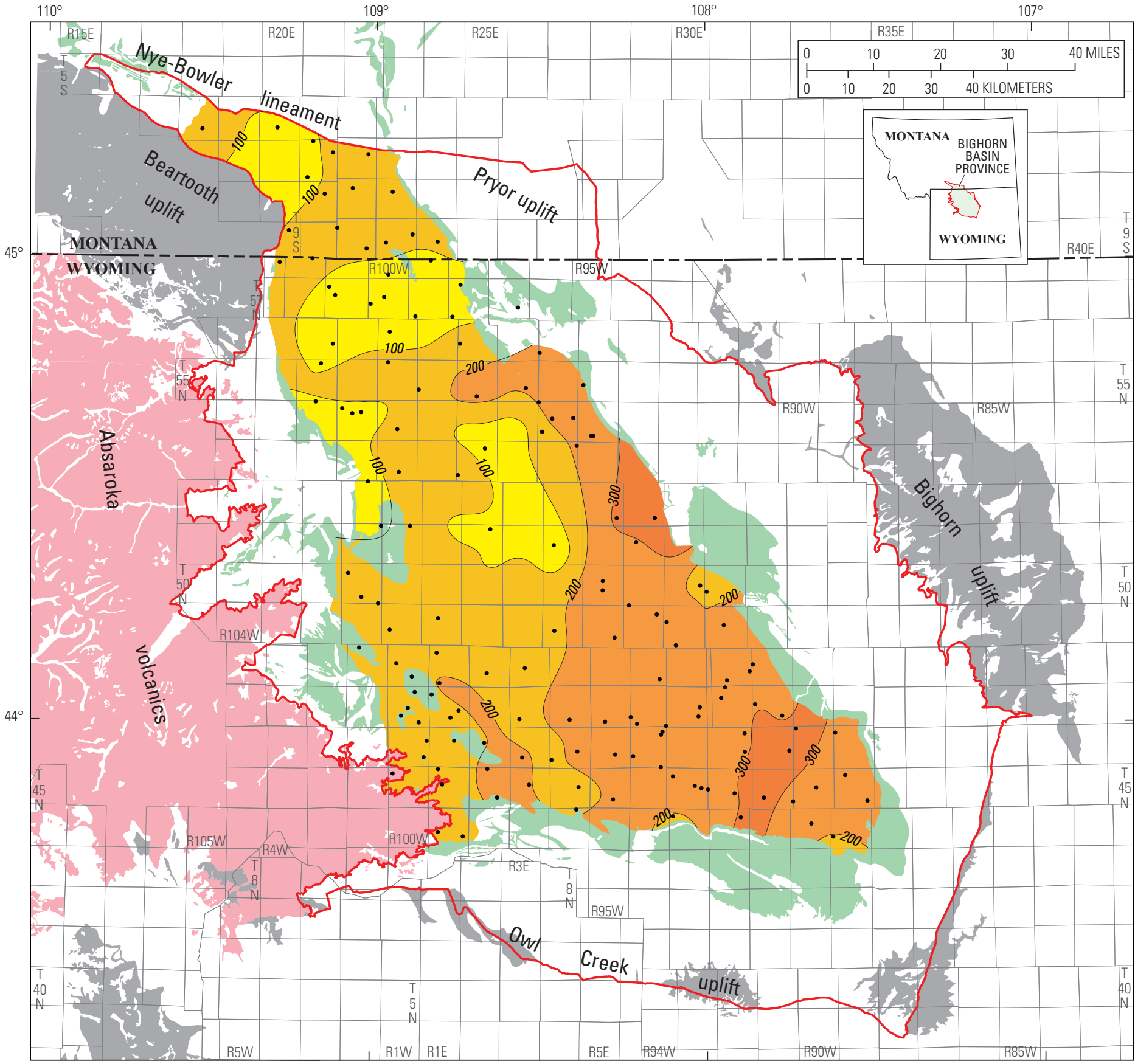

EXPLANATION

Tertiary volcanic rocks

Cody Shale outcrop

Precambrian rocks

Bighorn Basin Province boundary

Thickness contour-Contour

interval 100 feet

- Well location

Thickness, in feet

\begin{tabular}{|r|}
\hline-100 \\
\hline-200 \\
\hline-300 \\
\hline
\end{tabular}

Base from U.S. Geological Survey, 2010, $2,000,000$-scale digital data ambert Conformal Conic projection

Standard parallels $41^{\circ}$ and $45^{\circ}$

Central meridian- $107^{\circ} 30^{\circ}$

atitude of origin $41^{\circ}$, meters

North American Datum of 1983 (NAD 83)

Figure 13. Isopach map of the Sage Breaks equivalent interval in the lower part of the Cody

Shale. This map includes the interval from the base of the

"chalk kick" marker to the top of the uppermost sandstone in the underlying Frontier Formation. Modified from Finn (2014).

Thickness interval 100 feet. 


\section{Acknowledgments}

The manuscript and sheet benefited from reviews by Ron Johnson, Jon Haacke, Ofori Pearson, Janet Slate, and Dave Ferderer of the U.S. Geological Survey (USGS); their suggestions and comments are greatly appreciated. Important data about fossil collections and locations were provided by K.C. McKinney, curator of the USGS fossil collection in Denver, Colo.

\section{References Cited}

Biggs, Paul, and Espach, R.H., 1960, Petroleum and natural gas fields in Wyoming: U.S. Bureau of Mines Bulletin 582, $538 \mathrm{p}$.

Cobban, W.A., 1951, Scaphoid cephalopods of the Colorado group: U.S. Geological Survey Professional Paper 239, 42 p. [Also available at https://pubs.usgs.gov/pp/0239/report.pdf.]

Cobban, W.A., 1969, The Late Cretaceous ammonites Scaphites leei Reeside and Scaphites hippocrepis (DeKay) in the Western Interior of the United States: U.S. Geological Survey Professional Paper 619, 29 p. [Also available at https://pubs.usgs.gov/pp/0619/report.pdf.]

Cobban, W.A., Dyman, T.S., and Porter, K.W., 2005, Paleontology and stratigraphy of upper Coniacian-middle Santonian ammonite zones and application to erosion surfaces and marine transgressive strata in Montana and Alberta: Cretaceous Research, v. 26, p. 429-449.

Cobban, W.A., Walaszczyk, Ireneusz, Obradovich, J.D., and McKinney, K.C., 2006, A USGS zonal table for the Upper Cretaceous middle Cenomanian-Maastrichtian of the Western Interior of the United States based on ammonites, inoceramids, and radiometric ages: U.S. Geological Survey Open-File Report 2006-1250, 45 p. [Also available at https:// pubs.usgs.gov/of/2006/1250/pdf/OF06-1250_508.pdf.]

De Bruin, R.H., 1993, Overview of oil and gas geology of Wyoming, in Snoke, A.W., Steidtman, J.R., and Roberts, S.M., eds., Geology of Wyoming: Geological Survey of Wyoming Memoir no. 5, p. 836-873.

Durham, L.S., 2012a, Mancos-Niobrara play full of surprises: American Association of Petroleum Geologists Explorer, v. 33 , no. 8 , p. $14-18$.

Durham, L.S., 2012b, What is the tally of Niobrara value?: American Association of Petroleum Geologists Explorer, v. 33 , no. 8 , p. 20.

Durham, L.S., 2013, Rocky operators move cautiously ahead: American Association of Petroleum Geologists Explorer, v. 34 , no. 6 , p. $6-8$.
Finn, T.M., 2010, Subsurface stratigraphic cross sections showing correlation of Cretaceous and Lower Tertiary rocks in the Bighorn Basin, Wyoming and Montana, chap. 6 of Petroleum Systems and Geologic Assessment of Oil and Gas Resources in the Bighorn Basin Province, Wyoming and Montana: U.S. Geological Survey Digital Data Series DDS-69-V, 14 p., CD-ROM.

Finn, T.M., 2014, Lower Cody Shale (Niobrara equivalent) in the Bighorn Basin, Wyoming and Montana-Thickness, distribution, and source rock potential: U.S. Geological Survey Scientific Investigations Report 2013-5138, 32 p., accessed February 2, 2016, at https://pubs.usgs.gov/ $\operatorname{sir} / 2013 / 5138 /$.

Finn, T.M., 2017, Stratigraphic cross sections of the Niobrara interval of the Cody Shale and associated rocks in the Wind River Basin, central Wyoming: U.S. Geological Survey Scientific Investigations Map 3370, 19 p. 1 sheet, accessed February 2, 2018, at https://pubs.usgs.gov/sim/3370/ sim3370.pdf.

Finn, T.M., Kirschbaum, M.A., Roberts, S.B., Condon, S.M., Roberts, L.N.R., and Johnson, R.C., 2010, CretaceousTertiary Composite Total Petroleum System (503402), Bighorn Basin, Wyoming and Montana, chap. 3 of Petroleum Systems and Geologic Assessment of Oil and Gas Resources in the Bighorn Basin Province, Wyoming and Montana: U.S. Geological Survey Digital Data Series DDS69-V, 146 p., CD-ROM.

Fox, J.E., and Dolton, G.L., 1989, Petroleum geology of the Wind River and Bighorn Basins, Wyoming and Montana: U.S. Geological Survey Open-File Report 87-450-P, 41 p.

Fox, J.E., and Dolton, G.L., 1996, Petroleum geology of the Bighorn Basin, north-central Wyoming and south-central Montana, in Bowen, C.E., Kirkwood, S.C., and Miller, T.S., eds., Resources of the Bighorn Basin, 47th annual Field Conference Guidebook: Wyoming Geological Association Guidebook, p. 19-39.

Gill, J.R., and Burkholder, R.E., 1979, Measured sections of the Montana Group and equivalent rocks from Montana and Wyoming: U.S. Geological Survey Open-File Report 79-1143, $202 \mathrm{p}$.

Gries, R.R., Dolson, J.C., and Raynolds, R.G.H., 1992, Structural and stratigraphic evolution and hydrocarbon distribution, Rocky Mountain Foreland, in Macqueen, R.W., and Leckie, D.A., eds., Foreland basins and fold belts: American Association of Petroleum Geologists, Memoir 55, p. 395-425.

Hagen, E.S., and Surdam, R.C., 1984, Maturation history and thermal evolution of Cretaceous source rocks of the Bighorn Basin, Wyoming and Montana, in Woodward, J., Meissner, F.F., and Clayton, J.L., eds., Hydrocarbon source rocks of the greater Rocky Mountain region: Rocky Mountain Association of Geologists Guidebook, p. 321-338. 
Hattin, D.E., 1975, Petrology and origin of fecal pellets in Upper Cretaceous strata of Kansas and Saskatchewan: Journal of Sedimentary Petrology, v. 45, no. 3, p. 686-696.

Hawkins, S.J., 2016, Assessment of continuous (unconventional) oil and gas resources in the Late Cretaceous Mancos Shale of the Piceance Basin Province, Colorado and Utah, 2016: U.S. Geological Survey Fact Sheet 2016-3030, 4 p.

Hewett, D.F., and Lupton, C.T., 1917, Anticlines in the southern part of the Big Horn Basin, Wyoming: U.S. Geological Survey Bulletin 656, 192 p. [Available at https://pubs.usgs. gov/bul/0656/report.pdf.]

Hicks, J.F., Obradovich, D.D., and Tauxe, L., 1995, A new calibration point for the Late Cretaceous time scale-The ${ }^{40} \mathrm{Ar} /{ }^{39} \mathrm{AR}$ isotopic age of the $\mathrm{C} 33 \mathrm{r} / \mathrm{C} 33 \mathrm{n}$ geomagnetic reversal from the Judith River Formation (Upper Cretaceous), Elk Basin, Wyoming, USA: The Journal of Geology, v. 103, p. 243-256.

Johnson, R.C., Crovelli, R.A., Lowell, B.G., and Finn, T.M., 1999, An assessment of in-place gas resources in the low-permeability basin-centered gas accumulation of the Bighorn Basin, Wyoming and Montana: U.S. Geological Survey Open-File Report 99-315-A, 123 p.

Johnson, R.C., and Finn, T.M., 1998, Is there a basin-centered gas accumulation in Upper Cretaceous rocks in the Bighorn Basin?, in Keefer, W.R., and Goolsby, J.E., eds., Cretaceous and Lower Tertiary rocks of the Bighorn Basin, Wyoming and Montana, 49th annual field conference guidebook: Wyoming Geological Association Guidebook, p. 257-273.

Johnson R.C., Keefer, W.R., Keighin, C.W., and Finn, T.M., 1998, Detailed outcrop studies of the upper part of the Upper Cretaceous Cody Shale and Upper Cretaceous Mesaverde, Meeteetse, and Lance Formations, Bighorn Basin, Wyoming, in Keefer, W.R., and Goolsby, J.E., eds., Cretaceous and Lower Tertiary rocks of the Bighorn Basin, Wyoming and Montana, 49th annual field conference guidebook, 1998: Wyoming Geological Association Guidebook, p. 59-78.

Johnson R.C., and Keighin, C.W., 1998, Origins of natural gases from Upper Cretaceous reservoirs, Bighorn Basin, Wyoming and Montana, and comparison with gases from the Wind River Basin, Wyoming, in Keefer, W.R., and Goolsby, J.E., eds., Cretaceous and Lower Tertiary rocks of the Bighorn Basin, Wyoming and Montana, 49th annual field conference guidebook: Wyoming Geological Association Guidebook, p. 233-249.

Kauffman, E.G., 1977, Geological and biological overviewWestern Interior Cretaceous basin, in Kauffman, E.G., ed., Cretaceous facies, faunas, and paleoenvironments across the Western Interior Basin: The Mountain Geologist, v. 14, nos. 3 and 4, p. 75-99.
Kauffman, E.G., and Caldwell, W.G.E., 1993, The Western Interior Basin in space and time, in Caldwell, W.G.E., and Kauffman, E.G., eds., Evolution of the Western Interior Basin: Geological Association of Canada Special Paper 39, p. 1-30.

Keefer, W.R., 1972, Frontier, Cody, and Mesaverde Formations in the Wind River and southern Bighorn Basins, Wyoming: U.S. Geological Survey Professional Paper 495-E, 23 p.

Keefer, W.R., Finn, T.M., Johnson, R.C., Keighin, C.W., 1998, Regional stratigraphy and correlation of Cretaceous and Paleocene rocks, Bighorn Basin, Wyoming and Montana, in Keefer, W.R., and Goolsby, J.E., eds., Cretaceous and Lower Tertiary rocks of the Bighorn Basin, Wyoming and Montana, 49th annual field conference guidebook: Wyoming Geological Association Guidebook, p. 1-30.

Kirschbaum, M.A., Merewether, E.A., and Condon, S.M., 2009, Stratigraphy and age of the Frontier Formation and associated rocks, central and southern Bighorn Basin, Wyoming - Surface to subsurface correlation: The Mountain Geologist, v. 46, no. 4, p. 125-147.

Longman, M.W., Luneau, B.A., and Landon, S.M., 1998, Nature and distribution of Niobrara lithologies in the Cretaceous Western Interior Seaway of the Rocky Mountain Region: The Mountain Geologist, v. 35, no. 4, p. 137-170.

Matthews, Vince, 2011, Colorado's new oil boom-the Niobrara: Colorado Geological Survey Rock Talk, v. 13, no. $1,11 \mathrm{p}$.

McGookey, D.P., Haun, J.D., Hale, L.A., Goodale, H.G., McCubbin, D.G., Weimer, R.J., and Wulf, G.R., 1972, Cretaceous System, in Mallory, W.W., Mudge, M.R., Swanson, V.E., Stone, D.S., and Lumb, W.E., eds., Geologic atlas of the Rocky Mountain Region: Rocky Mountain Association of Geologists, p. 190-228.

McKinney, K.C., and Cobban, W.A., 2018, USGS Denver Mesozoic Catalog for 14595 fossil localities from the Rocky Mountain Region (1933-2017): U.S. Geological Survey data release, accessed September 9, 2018, at https://doi. org/10.5066/F7057F62

Meissner, F.F., Woodward, J., and Clayton, J.L., 1984, Stratigraphic relationships and distribution of source rocks in the greater Rocky Mountain region, in Woodward, J., Meissner, F.F., and Clayton, J.L., eds., Hydrocarbon source rocks of the greater Rocky Mountain region: Rocky Mountain Association of Geologists, p. 1-34.

Merewether, E.A., 1996, Stratigraphy and tectonic implications of Upper Cretaceous rocks in the Powder River Basin, northeastern Wyoming and southeastern Montana: U.S. Geological Survey Bulletin 1917-T, 92 p. 
Merewether, E.A., Cobban, W.A., and Tillman, R.W., 2010, Outcrops, fossils, geophysical logs, and tectonic interpretations of the Upper Cretaceous Frontier Formation and contiguous strata in the Bighorn Basin, Wyoming and Montana: U.S. Geological Survey Scientific Investigations Report 2009-5256, 52 p.

Merewether, E.A., Cobban, W.A., and Obradovich, J.D., 2011, Biostratigraphic data from Upper Cretaceous FormationsEastern Wyoming, central Colorado, and northeastern New Mexico: U.S. Geological Survey Scientific Investigations Map 3175, pamphlet 10 p., 2 sheets [cross sections]. Accessed February 2, 2014, at https://pubs.usgs.gov/ sim/3175/maps/SIM3175pamphlet-508.pdf

Merewether, E.A., and McKinney, K.C., 2015, Chronostratigraphic cross section of Cretaceous formations in western Montana, western Wyoming, eastern Utah, northeastern Arizona, and northwestern New Mexico, U.S.A.: U.S. Geological Survey Open-File Report 2015-1087, pamphlet 10 p., 1 sheet [cross section]. Accessed February 2, 2014, at https:// pubs.usgs.gov/of/2015/1087/

Molenaar, C.M., and Rice, D.D., 1988, Cretaceous rocks of the Western Interior Basin, in Sloss, L.L., ed., The Geology of North America, Sedimentary cover-North American craton, U.S.: Boulder, Colo., Geological Society of America, v. D-2, p. $77-82$.

Nuccio, V.F., and Finn, T.M., 1998, Thermal maturity and petroleum generation history of Cretaceous and Tertiary source rocks, Bighorn Basin, Wyoming and Montana, in Keefer, W.R., and Goolsby, J.E., eds., Cretaceous and Lower Tertiary rocks of the Bighorn Basin, Wyoming and Montana, 49th annual field conference guidebook: Wyoming Geological Association Guidebook, p. 211-231.

Ryder, R.T., 1987, Oil, gas, and coal resource of the McCullough Peaks Wilderness study area, Bighorn Basin, Wyoming: U.S. Geological Survey Open-File Report 97-646, 59 p.

Sonnenberg, S.A., 2011, The Niobrara Petroleum SystemA new resource play in the Rocky Mountain Region, in Estes-Jackson, J.E., and Anderson, D.S., eds., Revisiting and revitalizing the Niobrara in the central Rockies: Rocky Mountain Association of Geologists, p. 13-32.

Steidtmann, J.R., 1993, The Cretaceous foreland basin and its sedimentary record, in Snoke, A.W., Steidtmann, J.R., and Roberts, S.M., eds., Geology of Wyoming: Geological Survey of Wyoming Memoir no. 5, p. 250-271.

Surdam, R.C., Jiao, Z.S., and Heasler, H.P., 1997, Anomalously pressured gas compartments in Cretaceous rocks of the Laramide basins of Wyoming - A new class of hydrocarbon accumulation, in Surdam, R.C., ed., Seals, traps, and the petroleum system: American Association of Petroleum Geologists Memoir 67, p. 199-222.
Taylor, J., and Sonnenberg, S.A., 2014, Reservoir characterization of the Niobrara Formation, southern Powder River Basin, Wyoming: The Mountain Geologist, v. 51, no. 1, p. 83-108.

Williams, P., and Lyle, D., 2011, Bring in the rigs, chap. 2 of Estes-Jackson, J.E., and Anderson, D.S., eds., Revisiting and revitalizing the Niobrara in the central Rockies: Rocky Mountain Association of Geologists, 33 p.

Publishing support provided by: Denver Publishing Service Center

For more information concerning this publication, contact:

Center Director, USGS Central Energy Resources Science Center Box 25046, Mail Stop 939

Denver, CO 80225

(303) 236-1647

Or visit the Central Energy Resources Science Center Web site at: http://energy.usgs.gov 
$\stackrel{\infty}{\frac{1}{9}}$

言 